\title{
HEALTH STATUS OF CHILDREN POPULATION UNDER INFLUENCE OF THE CHEMICAL COMPOSITION OF DRINKING WATER
}

D0I: 10.36740/WLek202004134

\author{
Luibov V. Hryhorenko, Dmytro G. Bashmakov \\ STATE INSTITUTION “DNIPROPETROVSK MEDICAL ACADEMY MINISTRY OF HEALTH OF UKRAINE”, DNIPROPETROVSK, UKRAINE
}

\begin{abstract}
The aim: To study health status among the children in connection with a prolonged exposure of drinking water from decentralized systems.

Materials and methods: The prevalence rates of diseases among children of rural areas were studied according to the statistical reports in Dnipropetrovsk region health information center from 2008 to 2013 using statistical form № 12 (totally 220 reports). The distribution of rural areas in the region was based on the cluster analysis. The horizontal dendrogram showing similarity between the research areas in a multidimensional space. Cluster analysis includes 2 groups of rural districts in Dnipropetrovsk region. Results: It is established that with increase of $\mathrm{pH}>7.5-7.6$ in water of decentralized systems decreased the prevalence in the majority of nosologies: diseases of the blood and hematopoietic organs $\left(r_{s}=0,331 ; p<0,001\right)$, musculoskeletal system $\left(r_{s}=-0,174 ; p<0,001\right)$, anemia $\left(r_{s}=-0,331 ; p<0,001\right)$, congenital anomalies $\left(r_{s}=-0,272 ; p=0,002\right)$ among children population.

Conclusions: Among those children, who consumed drinking water from wells with content of some essential trace elements on the limits of MPC: $71 \%$ did not suffer from chronic diseases of the circulatory system $\left(\mathrm{Fe}>0.144 \mathrm{mg} / \mathrm{dm}^{3}\right) ; 59 \%$ did not suffer from the diseases of digestive system (Cu $\left.>0.089 \mathrm{mg} / \mathrm{dm}^{3}\right)$, and $60 \%$ had no congenital abnormalities of circulatory system $\left(\mathrm{Mn}>0.099 \mathrm{mg} / \mathrm{dm}^{3}\right)$.
\end{abstract}

KEY WORDS: prevalence of disease; children's population; cluster analysis; decentralized sources; dendrogram

Wiad Lek. 2020;73(4):796-800

\section{INTRODUCTION}

In today's context, a scale of noncommunicable diseases is worrying today, demonstrating a growing trend and negative impact on the public health [1]. Problem of safe and accessible drinking water is attracted worldwide attention nowadays, since use of poor drinking water can lead to the infectious and non-communicable diseases with serious consequences [2]. According to Honcharov O.V. et all [3], in Odessa region the most polluted from the sources of decentralized water supply were water samples from individual mine wells, which is connected with violation of sanitary requirements when planning the construction of private farms (not kept distances from wells to yard toilets, livestock buildings, gardens, application of mineral fertilizers), the specific levels of soil mineralization and groundwater in the region. Lototskaya O.V. et all [4] found that high risk of adverse effects in the children is possible in wells water with content of nitrates 3-7 MPC in two districts of Ternopilskyi region. In many regions of Ukraine, formation of groundwater chemical composition in the rural areas is facilitated at the presence of limestone and gypsum rocks, which can saturate groundwater with certain chemical elements and increase of average annual rainfall and average air temperature [5]. All this, according to national scientists [6], leads to the decrease amount of groundwater in the shallow decentralized individual sources of water supply and to increase concentration of water-diluted chemicals: hardness, iron, nitrates, copper, manganese, etc. Dnipropetrovsk region is not the exception, where part of the settlements use only groundwater for drinking water supply.

\section{THE AIM}

To study health status of the children population in relation to a long-term effects of drinking water from decentralized systems.

\section{MATERIALS AND METHODS}

The prevalence rates of diseases among children of rural areas were studied according to the statistical reports in Dnipropetrovsk region health information center from 2008 to 2013 using statistical form № 12 (totally 220 reports). The distribution of rural areas in the region was based on the cluster analysis. The horizontal dendrogram showing similarity between the research areas in a multidimensional space. Cluster analysis allowed us to outline 2 groups of rural districts in Dnipropetrovsk region: the first group included 11 districts located in the north within Dnipro river basin: Tsarychanskyi, Magdalynivskyi, Pavlogradskyi, Petrykivskyi, Verkhniodniprovskyi, Krynychanskyi, Dnipropetrovskyi, Piatykhatskyi, Mezhivskyi, Novomoskovskyi. The second 


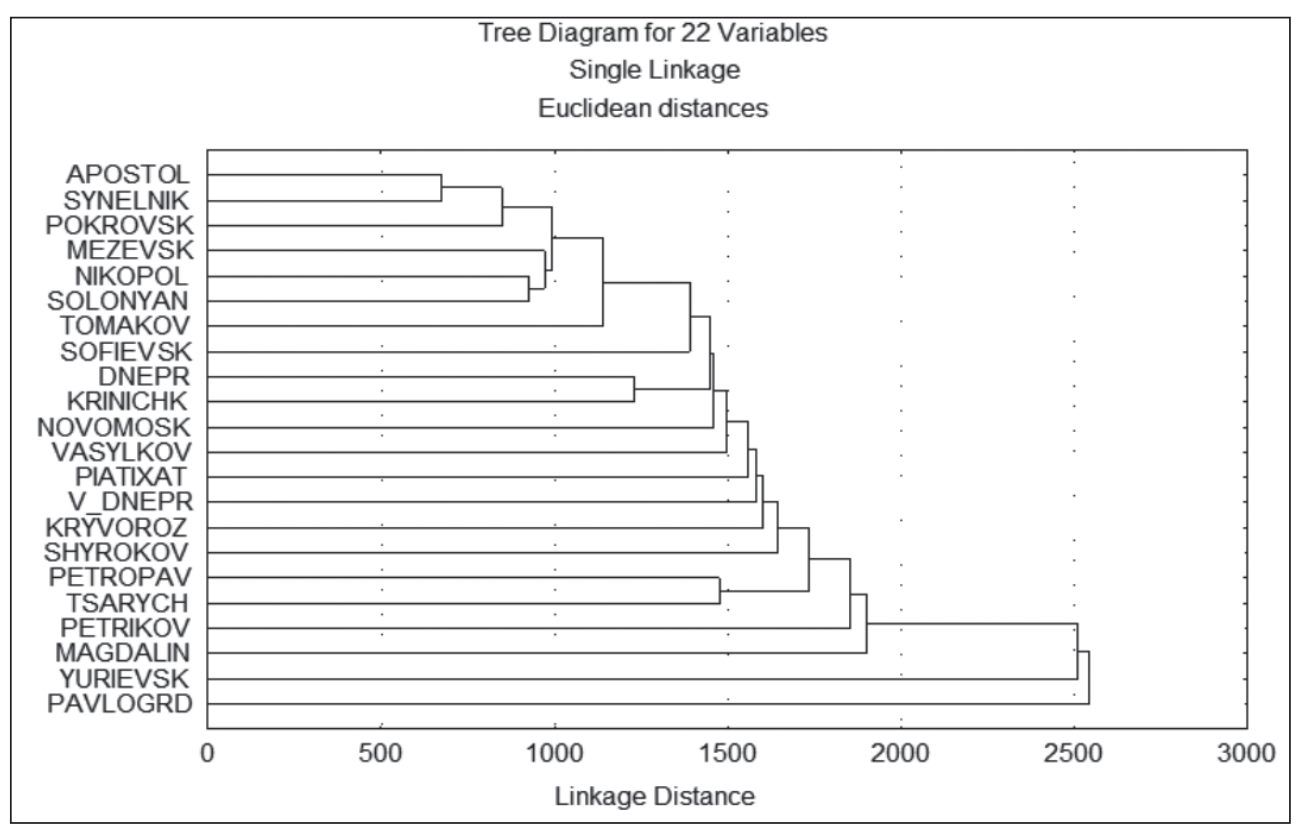

Fig. 1. Cluster analysis of the distribution rural districts of Dnipropetrovsk region in a multidimensional space with calculation Euclid distances (y-axis). group consisted of 11 rural districts located in the south of the region outside the Dnipro river basin and using predominantly decentralized water supply systems: Kryvorizhskyi, Sofiivskyi, Shirokivskyi, Apostolivskyi, Tomakivskyi, Petropavlivskyi, Pokrovskyi, Solonianskyi, Vasylkivskyi, Nykopolskyi (Fig. 1).

To assess health status of children in the rural districts of Dnepropetrovsk region, levels of a disease prevalence were analyzed for individual nosological groups, according to ICD-X, stratified by age composition in the rural districts, the choice of which was based on the homogenity types of water supply systems: group 1 and group 2 . In the study was used $2^{\text {nd }}$ group of rural districts, which is represented predominantly by decentralized water supply, or imported drinking water. Provision of rural population with drinking water is carried out by means of individual mine or tubular wells. The average annual indicators of drinking water quality were monitored in accordance with DSanPin 2.2.4-171-10 and DSTU 4808:2007 [7, 8]. According to the official statistical reports [9], a data- base on the health of children population was created. Statistical grouping and development of materials on the prevalence of diseases in the children population were conducted according to the International Statistical Classification of Diseases (ICD-X) [10]. Mathematical processing included the following methods: calculation of primary statistical indicators, identification of differences between groups by statistical characteristics; establishing relationships between variables with using a parametric and non-parametric correlation analysis (conjunction tables) [11]. Multidimensional statistics were used as auxiliary mathematical methods at the separate stages of research: cluster analysis. Horizontal dendrograms were used for cluster analysis, showing similarity between the objects of study, which was measured in the multidimensional space by calculating Euclid distance [12]. Excel was used for initial preparation of the tables and intermediate calculations. Most of the mathematical processing was performed on PC using the standard statistical package STATISTICA 10.0 portable.

Table I. Influence of water pH on the prevalence diseases of blood and hematopoietic organisms at the children population in the rural districts*

\begin{tabular}{|c|c|c|c|}
\hline \multirow[b]{2}{*}{ Graduation of effect } & \multicolumn{2}{|c|}{ Graduation of factor } & \multirow[b]{2}{*}{ Amount } \\
\hline & $\begin{array}{c}\text { Children } \\
\text { who are not sick }\end{array}$ & $\begin{array}{c}\text { Children } \\
\text { who are sick }\end{array}$ & \\
\hline The amount of children who do not fall ill & 30 & 32 & 62 \\
\hline Children who drink water with $\mathrm{pH}<7.5-7.6, \%$ & 48,39 & 51,61 & \\
\hline Totally, \% & 22,73 & 24,24 & 46,97 \\
\hline The amount of children who are ill & 56 & 14 & 70 \\
\hline Children who drink water with $\mathrm{pH}>7.5-7.6, \%$ & 80,00 & 20,00 & \\
\hline Totally, \% & 42,42 & 10,61 & 53,03 \\
\hline Amount & 86 & 46 & 132 \\
\hline Totally, \% & 65,15 & 34,85 & 100,00 \\
\hline
\end{tabular}

Note $^{*}-$ a link is statistically significant $\left(r_{s}=-0,331 ; p<0,001\right)$. 
Table II. Impact of copper on the prevalence of anemia at the children population in the rural districts*

\begin{tabular}{|c|c|c|c|}
\hline \multirow[b]{2}{*}{ Graduation of effect } & \multicolumn{2}{|c|}{ Graduation of factor } & \multirow[b]{2}{*}{ Amount } \\
\hline & $\begin{array}{c}\text { Children } \\
\text { who are not sick }\end{array}$ & $\begin{array}{c}\text { Children } \\
\text { who are sick }\end{array}$ & \\
\hline The amount of children who do not fall ill & 10 & 13 & 23 \\
\hline Children who drink water with $\mathrm{Cu}<0.089 \mathrm{mg} / \mathrm{dm}^{3}, \%$ & 43,48 & 56,52 & \\
\hline Totally, \% & 7,58 & 9,85 & 17,42 \\
\hline The amount of children who are ill & 76 & 33 & 109 \\
\hline Children who drink water with $\mathrm{Cu}>0,089 \mathrm{mg} / \mathrm{dm}^{3}, \%$ & 69,72 & 30,28 & \\
\hline Totally, \% & 57,58 & 25,00 & 82,58 \\
\hline Amount & 86 & 46 & 132 \\
\hline Totally, \% & 65,15 & 34,85 & 100,00 \\
\hline
\end{tabular}

Note $^{*}$ - a link is statistically significant $\left(r_{s}=-0,209 ; p<0,001\right)$.

Table III. Impact of copper on the prevalence of a digestive system diseases at the children population in the rural districts*

\begin{tabular}{|c|c|c|c|}
\hline \multirow[b]{2}{*}{ Graduation of effect } & \multicolumn{2}{|c|}{ Graduation of factor } & \multirow[b]{2}{*}{ Amount } \\
\hline & $\begin{array}{c}\text { Children } \\
\text { who are not sick }\end{array}$ & $\begin{array}{c}\text { Children } \\
\text { who are sick }\end{array}$ & \\
\hline The amount of children who do not fall ill & 6 & 17 & 23 \\
\hline Children who drink water with $\mathrm{Cu}<0.089 \mathrm{mg} / \mathrm{dm}^{3}, \%$ & 26,09 & 73,91 & \\
\hline Totally, \% & 4,55 & 12,88 & 17,42 \\
\hline The amount of children who are ill & 64 & 45 & 109 \\
\hline Children who drink water with $\mathrm{Cu}>0,089 \mathrm{mg} / \mathrm{dm}^{3}, \%$ & 58,72 & 41,28 & \\
\hline Totally, \% & 48,48 & 34,09 & 82,58 \\
\hline Amount & 70 & 62 & 132 \\
\hline Totally, \% & 53,03 & 46,97 & 100,00 \\
\hline
\end{tabular}

Note * - a link is statistically significant $\left(r_{s}=-0,248 ; p=0,044\right)$.

\section{RESULTS AND DISCUSSION}

In the decentralized water supply systems, the study effect of $\mathrm{pH}$ on a prevalence of blood diseases and hematopoietic organs among the children from (0 to 14$)$ years revealed that the greater value of $\mathrm{pH}$ was in water $(\mathrm{pH}>7.5-7.6)$, the lower was prevalence of this class of disease, relationship is significant $\left(r_{s}=-0.331 ; p<0.001\right)$. It was found that with increasing $\mathrm{pH}>7.5-7.6$ in water, $80 \%$ of children do not get ill with chronic diseases of blood and hematopoietic organs (table I).

A similar pattern is found between copper content in the decentralized water systems and prevalence of anemia at the children: if $\mathrm{Cu}$ content is greater than $0.089 \mathrm{mg} /$ $\mathrm{dm}^{3}$, then prevalence of anemia in the rural districts is probably lower $\left(r_{s}=-0,209 ; p<0,001\right)$. As among those children who consume drinking water with high copper content, $69.7 \%$ do not suffer from anemia, which is explained by the beneficial effect of this essential heavy metal on a blood-forming function of the organism of children (table II).

As a result of our study, it was found that $\mathrm{pH}>7.5-7.6$ in well water had a significant effect on reducing the prevalence majority of nosologies at the children: anemia
$\left(r_{S}=-0,331 ; p<0,001\right)$, diseases of musculoskeletal system $\left(r_{s}=-0,174 ; p<0,001\right)$, congenital anomalies - relationship is negative, significant $\left(r_{s}=-0,272 ; p=0,002\right)$. The beneficial effect of $\mathrm{pH}$ in the range of 7.5-7.6 is explained by the healing properties of drinking water from many wells located in the countryside and involvement in metabolic processes at the children. Among children who consume drinking water with $\mathrm{pH}>7.5-7.6,80 \%$ are not diagnosed with prevalence of anemia; $67 \%$ - with chronic diseases of the musculoskeletal system; $64 \%$ -have no congenital anomalies. Copper is an important trace element, which deficiency causes in women infertility, various malformations, while excess of this heavy metal can cause embryotoxic effect. We have shown that excess of copper in the drinking water has a significant effect on reducing prevalence of a digestive system diseases among children $\left(r_{s}=-0,248 ; p=0,044\right)$, since $59 \%$ of children who use water with excess of $\mathrm{Cu}>$ $0.089 \mathrm{mg} / \mathrm{dm}^{3}$ do not suffer from chronic diseases of this class (table III).

It is known that iron is absorbed in the body with food and drinking water only on $5-10 \%$. The excess of this heavy metal in drinking water is probably causes a de- 
Table IV. Influence of iron on the prevalence of circulatory system diseases at the children population in the rural districts*

\begin{tabular}{|c|c|c|c|}
\hline \multirow[b]{2}{*}{ Graduation of effect } & \multicolumn{2}{|c|}{ Graduation of factor } & \multirow[b]{2}{*}{ Amount } \\
\hline & $\begin{array}{c}\text { Children } \\
\text { who are not sick }\end{array}$ & $\begin{array}{c}\text { Children } \\
\text { who are sick }\end{array}$ & \\
\hline The amount of children who do not fall ill & 52 & 52 & 104 \\
\hline Children who drink water with $\mathrm{Fe}<0,144 \mathrm{mg} / \mathrm{dm}^{3}, \%$ & 50,00 & 50,00 & \\
\hline Totally, \% & 39,39 & 39,39 & 78,79 \\
\hline The amount of children who are ill & 20 & 8 & 28 \\
\hline Children who drink water with Fe $>0,144 \mathrm{mg} / \mathrm{dm}^{3}, \%$ & 71,43 & 28,57 & \\
\hline Totally, \% & 15,15 & 6,06 & 21,21 \\
\hline Amount & 72 & 60 & 132 \\
\hline Totally, \% & 54,55 & 45,45 & 100,00 \\
\hline
\end{tabular}

Note $^{*}-$ a link is statistically significant $(r S=-0,176 ; p=0,044)$.

Table V. Effect of manganese on the prevalence of congenital anomalies of a circulatory system at the children population in the rural districts*

\begin{tabular}{|c|c|c|c|}
\hline \multirow[b]{2}{*}{ Graduation of effect } & \multicolumn{2}{|c|}{ Graduation of factor } & \multirow[b]{2}{*}{ Amount } \\
\hline & $\begin{array}{c}\text { Children } \\
\text { who are not sick }\end{array}$ & $\begin{array}{c}\text { Children } \\
\text { who are sick }\end{array}$ & \\
\hline The amount of children who do not fall ill & 1 & 5 & 6 \\
\hline Children who drink water with $\mathrm{Mn}<0,099 \mathrm{mg} / \mathrm{dm}^{3}, \%$ & 16,67 & 83,33 & \\
\hline Totally, \% & 0,76 & 3,79 & 4,55 \\
\hline The amount of children who are ill & 76 & 50 & 126 \\
\hline Children who drink water with $\mathrm{Mn}>0,099 \mathrm{mg} / \mathrm{dm}^{3}, \%$ & 60,32 & 39,68 & \\
\hline Totally, \% & 57,58 & 37,88 & 95,45 \\
\hline Amount & 77 & 55 & 132 \\
\hline Totally, \% & 58,33 & 41,67 & 100,00 \\
\hline
\end{tabular}

Note * - a link is statistically significant $\left(r_{s}=-0,184 ; p=0,034\right)$.

Table VI. Effect of dry residue on the prevalence of congenital anomalies of a circulatory system at the children population in the rural districts*

\begin{tabular}{|c|c|c|c|}
\hline \multirow[b]{2}{*}{ Graduation of effect } & \multicolumn{2}{|c|}{ Graduation of factor } & \multirow[b]{2}{*}{ Amount } \\
\hline & $\begin{array}{c}\text { Children } \\
\text { who are not sick }\end{array}$ & $\begin{array}{c}\text { Children } \\
\text { who are sick }\end{array}$ & \\
\hline The amount of children who do not fall ill & 57 & 33 & 90 \\
\hline $\begin{array}{l}\text { Children who drink water with dry residue less } \\
\qquad 195,083 \mathrm{mg} / \mathrm{dm}^{3}, \%\end{array}$ & 63,33 & 36,67 & \\
\hline Totally, \% & 43,18 & 25,00 & 68,18 \\
\hline The amount of children who are ill & 20 & 22 & 42 \\
\hline $\begin{array}{l}\text { Children who drink water with dry residue more } \\
\qquad 195,083 \mathrm{mg} / \mathrm{dm}^{3}, \%\end{array}$ & 47,62 & 52,38 & \\
\hline Totally, \% & 15,15 & 16,67 & 31,82 \\
\hline Amount & 77 & 55 & 132 \\
\hline Totally, \% & 58,33 & 41,67 & 100,00 \\
\hline
\end{tabular}

Note $^{*}$ - a link is statistically significant $\left(r_{s}=0,148 ; p=0,089\right)$.

crease in the prevalence of circulatory system diseases at the children $\left(r_{S}=-0,176 ; p=0,044\right)$. Thus, among children who consumed water with a high content of $\mathrm{Fe}>0.144$ $\mathrm{mg} / \mathrm{dm}^{3}, 71 \%$ did not suffer from chronic diseases of IX class (table IV).
Manganese, which is absorbed in the child's body on $3-4 \%$, contributed to the reduction prevalence of congenital anomalies of a circulatory system at the children population $\left(r_{s}=-0,184 ; p=0,034\right)$. In particular, among children who consumed drinking water with a content 
of $\mathrm{Mn}>0.099 \mathrm{mg} / \mathrm{dm}^{3}, 60 \%$ of children did not have this pathology (table V).

It has been found that drinking water with high chloride content more than $195,083 \mathrm{mg} / \mathrm{dm}^{3}$ is probably cause an increased incidence of congenital circulatory system abnormalities at the children of 14 years, relationship is positive, statistically significant $\left(r_{s}=0,148 ; p=0,089\right)$. Among those children who were constantly drinking water with a chloride content more than $195,083 \mathrm{mg} /$ $\mathrm{dm}^{3}, 48 \%$ have congenital abnormalities of a circulatory system (table VI).

According to the correlation analysis, there is a tendency to increase incidence among the children population. Thus, prevalence of skin and subcutaneous tissue diseases at the children ( $r=0.611, p=0.035)$ was correlated with a high nitrate content in well water $\left(>50 \mathrm{mg} / \mathrm{dm}^{3}\right)$. Sulphates are significantly influenced on the incidence of skin and subcutaneous tissue diseases in children $(r=0.724, p=0.008)$ and their prevalence $(r=0.718, p=0.009)$. However, presence of manganese in water carried out to the decreasing levels of digestive system diseases $(r=-0,31, p<0,001)$ and prevalence of the skin and subcutaneous tissue diseases $(r=-0,327$, $p<0,001)$, due to the beneficial effect of this heavy metal. Prevalence of the skin and subcutaneous tissue disease among children was correlated with magnesium $(r=0.36$, $p<0.001)$, zinc $(r=0.30, p<0.001)$ in the decentralized water system, which is explained by the presence of cumulative effect (since the general incidence is not detected primary, but also recorded in the recent years).

\section{CONCLUSIONS}

It is established that with increase of $\mathrm{pH}>7.5-7.6$ in water from the decentralized systems there is shown decreasing prevalence the majority of nosologies: diseases of the blood and hematopoietic organs $\left(r_{s}=-0,331 ; p<0,001\right)$, musculoskeletal system $\left(r_{s}=-0,174 ; p<0,001\right)$, anemia $\left(r_{s}=-0,331 ; p<0,001\right)$, congenital anomalies $\left(r_{s}=-0,272\right.$; $p=0,002)$ among children population. Among those children, who consumed drinking water from wells with a high content of some essential trace elements: $71 \%$ did not suffer from chronic diseases of the circulatory system $\left(\mathrm{Fe}>0.144 \mathrm{mg} / \mathrm{dm}^{3}\right) ; 59 \%$ did not suffer from the diseases of a digestive system $\left(\mathrm{Cu}>0.089 \mathrm{mg} / \mathrm{dm}^{3}\right)$, and $60 \%$ had no congenital abnormalities of a circulatory system $\left(\mathrm{Mn}>0.099 \mathrm{mg} / \mathrm{dm}^{3}\right)$.

\section{REFERENCES}

1. Leykhykh S.V., Melnichenko Yu.V., Novokhatska S.M., Implementation of scientific developments of the State Institution «IPH named by 0.M. Marzeyev NAMSU » to the Health Care Practice in 2017, Collection of abstracts of scientific-practical conference «Topical issues of public health and ecological safety of Ukraine». 2018; 18: $43-46$.

2. Stankevich V.V., Tarabarova S.B., Pollution of underground aquifers with a highly mineralized waters during working of Kryvbas mining and processing enterprises, Collection of abstracts of scientific-practical conference «Topical issues of public health and ecological safety of Ukraine». 2018; 18: 226-228.
3. Goncharov O.V., Bondarenko D.A., Maksimenko Yu.A., Hygienic aspects of providing the population of Odessa region with a good drinking water, Collection of abstracts of scientific-practical conference «Topical issues of public health and ecological safety of Ukraine». 2018; 18:233-235.

4. Lototska 0.V., Prokopor V.0., Risk assessment of drinking water with a high nitrate content for the health of population in Ternopilskyi region, Environment and Health. 2017; 4 (89): 20 - 24.

5. ProkopovV.0., Hygienic problems of water supply in Ukraine, Experience and prospects of scientific support problems of hygiene science. 2011: $106-132$.

6. Tunakova Yu.A., Stepanova N.V., Fayzullin R.I., Health risk assessment for the children with a drinking tap water, Modern problems of science and education. 2015; 6. Access mode: http://www.science-education. ru/ru/article/view?id=23767

7. Hygienic requirements for drinking water intended for human consumption: State Sanitary Rules and Regulations. DSanPin 2.2.4171-10. Access mode:http://normativ.ua/types/tdoc19074.php.

8. Sources of centralized drinking water supply. Hygienic and environmental requirements for water quality and selection rules: DSTU 4808: 2007, p.27.

9. Statistical reference book of Dnipropetrovsk region for 2008-2013 years. Directorate of Statistics in Dnipropetrovsk Oblast. 2014, p.563.

10. ICD X. International Statistical Classification of Diseases and Health Problems. 10th revision. 1995; 1 (1): 698.

11. Antomonov M.Yu., Mathematical processing and analysis of biomedical data. Book. - Kyiv: «Medinform», 2018, p.579.

12. Antomonov M.Yu., Mathematical processing and analysis of biomedical data. Book. - Kyiv: Malyi Druk, 2006, p.558.

Research work was carried out within a framework on the cathedral theme of the research work: "Scientific substantiation ecological and hygienic measures to prevent the negative influence of antropogenic factors on the environment and state of the population health", state registration number 0108U011276 (implementation period 2014-2018 years).

\section{ORCID and contributionship:}

Luibov V. Hryhorenko - 0000-0002-9517-5975 C,D,F

Dmytro G. Bashmakov - 0000-0002-0803-0920 A,B,E

\section{Conflicts of interest:}

Authors declare no conflict of interest.

\section{CORRESPONDING AUTHOR Luibov V. Hryhorenko}

St. Kryvorizhstali, ap. 12, flat 35, 50051, Kryvyi Rih, Ukraine

tel: +380680091847

e-mail: hryhorenkoluibov@ukr.net

Received: 09.07.2019

Accepted: 31.01 .2020

A - Work concept and design, B - Data collection and analysis, C - Responsibility for statistical analysis,

D-Writing the article, $\mathbf{E}$-Critical review, $\mathbf{F}$ - Final approval of the article 